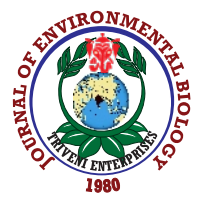

\title{
Evaluation of Atrichum undulatum as an effective indicator of lead pollution in soil
}

\author{
N. Yang ${ }^{1,2}$, M. Dong ${ }^{3 *}$, Z. Xu ${ }^{4 *}$, X. Zhou', Z. Xu ${ }^{3}$ and W. Ku ${ }^{3}$ \\ 'Key Laboratory of Key Technologies of Digital Urban-Rural Spatial Planning of Hunan Province, College of Architecture \& Urban Planning, Hunan City \\ University, Yyyang, Hunan-413000, China \\ ${ }^{2}$ Hunan Urban and Rural Ecological Planning and Restoration Engineering Research Center, Hunan City University, Yiyang, Hunan-413000, China \\ ${ }^{3}$ College of Materials and Chemical Engineering, Hunan City University, Yiyang Hunan-413000, China \\ ${ }^{4}$ Science and Technology Service Center of Hunan Province, Changsha, Hunan-410013, China \\ *Corresponding Author Email : dongmeng1001@163.com
}

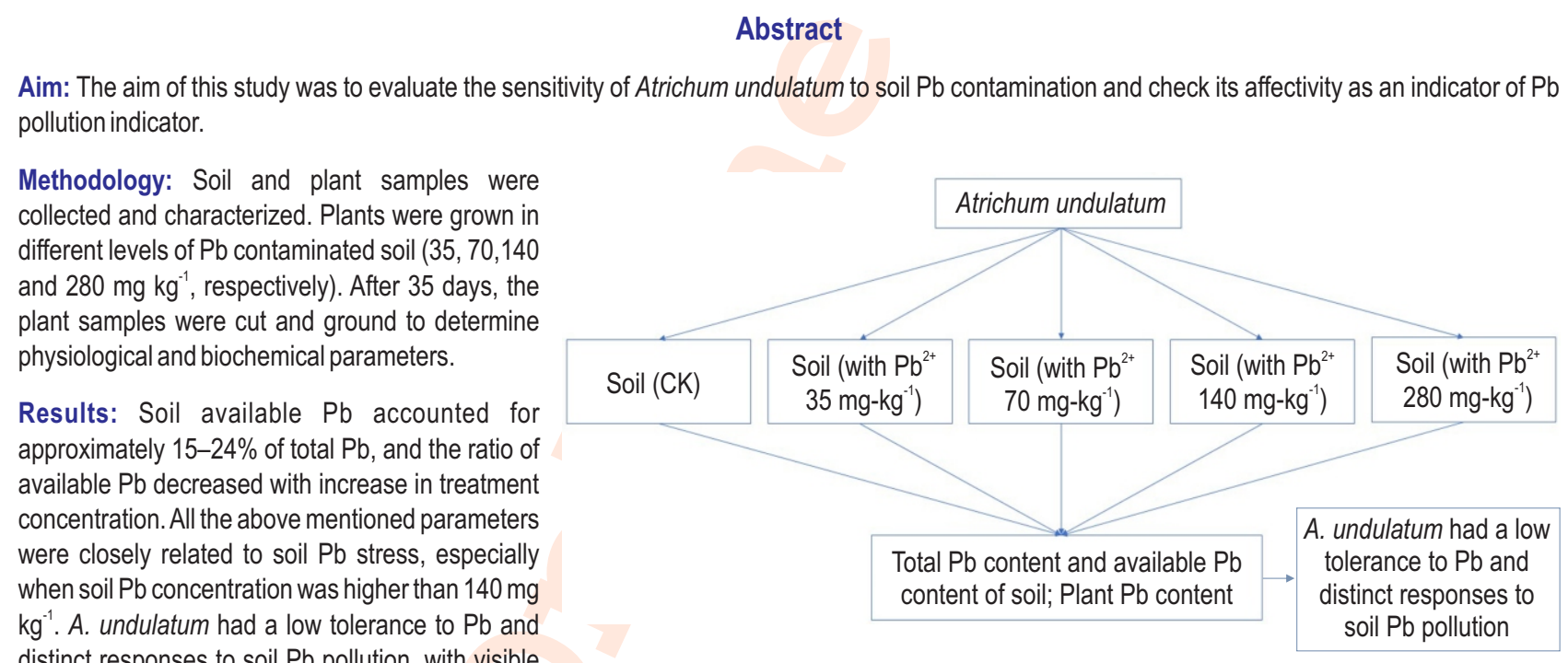
distinct responses to soil $\mathrm{Pb}$ pollution, with visible symptoms such as damaged sporophytes and gametophytes. When soil $\mathrm{Pb}$ concentration was in low concentration (70 and $\left.140 \mathrm{mg} \mathrm{kg}^{-1}\right)$, the leaves turned yellow and brown. When soil $\mathrm{Pb}$ concentration increased to $280 \mathrm{mg} \mathrm{kg}^{-1}$, the seta softened and kinked and eventually, the plants withered and died.

Interpretation: Changes in physiological and biochemical parameters of tested plants such as chlorophyll, soluble protein and MDA content were related to soil $\mathrm{Pb}$ stress, especially to soil bioavailable $\mathrm{Pb}$ content, and corresponded well to changes in soil $\mathrm{Pb}$ pollution level. The results suggest that $A$. undulatum can be used as indicators to monitor and evaluate $\mathrm{Pb}$ pollution in soil.

Key words: Atrichum undulatum, Biomonitoring, Pb-contaminated soil, Stress response

How to cite : Yang, N., M. Dong, Z. Xu, X. Zhou, Z. Xu and W. Ku: Evaluation of Atrichum undulatum as an effective indicator of lead pollution in soil. J. Environ. Biol., 42, 582-588 (2021). 


\section{Introduction}

Lead is a heavy metal pollutant, considered potentially hazardous, owing to its stabilization in soil; difficult to metabolize and degrade; carcinogenic, teratogenic, and mutagenic to human, livestock and crops; and bioaccumulate in humans and animals via food chain (Shibata et al., 2007; Liu et al., 2008). Currently, as a result of increasing production and use of $\mathrm{Pb}$ containing products, it has been estimated that $4-5$ million ha of cultivated land is contaminated by $\mathrm{Pb}$ in China, and annually $70-80 \%$ of $\mathrm{Pb}$ in industrial production waste is discharged into the soil. The increasing use of petroleum fuels with relatively high $\mathrm{Pb}$ content has increased $\mathrm{Pb}$ pollution in the soil, after atmospheric deposition. In addition, $\mathrm{Pb}$ pollution is mostly irreversible once the soil is contaminated, and the effects on crops are long lasting (Liu et al., 2008). Industries mostly use chemical detection methods to evaluate soil $\mathrm{Pb}$ pollution; the $\mathrm{Pb}$ content of soil is used as a basis to determine the ecological safety of soil $\mathrm{Pb}$. Recently, several researchers (Wang et al., 2014; Zhou et al., 2014) have pointed out that the actual toxicity of heavy metal elements in soil is closely related to soil's biological effectiveness.

Therefore, to test whether a soil has reached safety standards, one can consider the degree of damage caused by heavy metals in the soil to a biological body as a basis for determining toxicity. Thus, if a lower plant with high sensitivity to $\mathrm{Pb}$ is used to indicate soil $\mathrm{Pb}$ pollution through its growth condition and physiological reaction, it can provide a strong observational basis for determining toxicity levels. If $\mathrm{Pb}$-contaminated soil does not affect plant growth, then soil is considered safe and suitable for planting other crops otherwise, it indicates that the soil has exceeded the safety limit of $\mathrm{Pb}$ pollution and there is a risk of $\mathrm{Pb}$ contamination, and the soil is not suitable for planting crops. Some plants such as Juncus effuses (Sun et al., 2007), Arabis paniculata (Tang et al., 2009) can be used as Pb indicators. In contrast to terrestrial vascular plants, the bryophytes have a simple structure and low degree of tissue differentiation. Their surface is not covered with a stratum corneum or waxy layer and therefore, it is sensitive to pollutants in the environment. Heavy metal ions or dust particles, such as $\mathrm{Pb}$, can be directly absorbed by the epidermal parenchyma cells into the plant body, which causes the plant to rapidly display symptoms.

Therefore, it is suitable for real-time dynamic monitoring of environmental pollution. In addition, in-situ monitoring of bryophytes causes little disturbance to the environment and is a simple operation with low costs and a short monitoring period, making this method particularly valuable (Zhou et al., 2008; Lodenius, 2013; Abril et al., 2014; Chen et al., 2015; Esposito et al., 2018; Debén et al., 2018) and widely used in air, water and soil pollution monitoring all over the world (Conti and Cecchetti, 2001; Harmens and Norris, 2008; Zhou et al., 2008; Basile et al., 2015; Harguinteguy et al., 2015; Aboal et al., 2017;). Based on the above characteristics, the bryophyte monitoring method has been widely used in monitoring atmospheric and water metal pollution. However, research to determine whether this method can be used to monitor soil heavy metal contamination is limited. Structurally, the roots (pseudo-roots) of bryophytes also exhibit a strong response to the soil environment. Heavy metal ions in the soil can poison plants through pseudo-thin parenchyma cells. The principle of monitoring the atmosphere by aboveground parts of plants can be used theoretically to monitor heavy metal pollution in soil, which is worthy of further exploration. In this study, the bryophyte Atrichum undulatum, which is highly sensitive to $\mathrm{Pb}$ was used to preliminarily explore its stress response to soil $\mathrm{Pb}$ ions. The growth performance was observed and physiological by analyzed after implanted into soils with different concentrations of $\mathrm{Pb}$. The results provide a theoretical basis and technical reference for further development of biomonitoring technology for soil $\mathrm{Pb}$ pollution.

\section{Materials and Methods}

Tested plant material: A. undulatum plants were collected from farmland soil in Wanzihu, Dongting Lake, Hunan Province $\left(28^{\circ} 51^{\prime} 23.28^{\prime \prime} \mathrm{N}, 112^{\circ} 26^{\prime} 42.71^{\prime \prime} \mathrm{E}\right)$. As the base of the plant is generally clustered, the plants, roots, and $2-3 \mathrm{~cm}$ of soil were collected in small pieces, using a shovel. The collected source materials were placed in a water tank grid, ensuring that the roots were completely immersed and they were then gently agitated in water for 1-2 hr. During the rinsing process, the roots were protected from physical damage using a special plant root cleaning device developed in-house (CN PAT: CN208146522U). After washing the roots, they were transplanted into plastic pans containing $\mathrm{Pb}$-treated farm soil matrix.

Soil substrate treatment: After air drying and pulverizing, $2 \mathrm{~kg}$ of farmland soil was weighed and laid in a flat circular polyethylene shallow pan with a short disc height of $6 \mathrm{~cm}$ and diameter of 35 $\mathrm{cm}$. Based on the environmental reference value for $\mathrm{Pb}$ pollution in domestic field soil, the corresponding mass of $\mathrm{Pb}\left(\mathrm{No}_{3}\right)_{2}$ was calculated; $\mathrm{Pb}\left(\mathrm{NO}_{3}\right)_{2}$ was dissolved and fully mixed to ensure that the applied concentrations of $\mathrm{Pb}^{2+}$ in the soil matrix were 35.0 , $70.0,140.0$, and $280.0 \mathrm{mg} \mathrm{kg}^{-1}$, and soil samples without $\mathrm{Pb}$ $\left(\mathrm{NO}_{3}\right)_{2}$ were used as a control. Each treatment was repeated five times. The soil samples were static cultured for 35 days in natural indoor condition to make sure the soil properties were stable. Then, $A$. undulatum plants were transplanted in the shallow pans with treated soils in a net room, under conditions close to their natural environment, i.e., a temperate of $32-35^{\circ} \mathrm{C}$ and humidity of $86 \%$ and were sprayed with $300-500 \mathrm{~mL}$ tap water. The morphological characteristics and physiological parameters of the plants were measured once every two days since the second day after transplantation, and repeated five times, and the average test data was taken as the final test result.

Sample collection and analyses: The stems and leaves of plants were cut to determine the physiological and biochemical parameters. The cut samples were ground in a mixture of ethanol and acetone (1:1), extracted, and filtered, and the chlorophyll content was estimated using a 722 spectrophotometer (Shanghai Sunny Hengping Scientific Instrument Co., Ltd, Shanghai, China) (Yang, 2002). The samples were then ground with phosphate buffer $\left(0.1 \mathrm{mmol} \mathrm{L}^{-1}, \mathrm{pH} 7.8\right.$, containing 1\% PVPK30) and centrifuged for 8 $\mathrm{min}$ at $8000 \mathrm{rmin}^{-1}$. The soluble protein content in the crude extract 
was estimated by Coomassie Brilliant Blue G-250 colorimetric method, estimated by Malondialdehyde (MDA) content in each sample was estimated by thiobarbituric acid colorimetric method.

$\mathrm{Pb}$ content was determined using a Shimadzu AA-6300 graphite furnace atomic absorption spectrophotometer (Shimadzu Scientific Instruments, Inc., Columbia, MA, USA). For each treatment, $0.3 \mathrm{~g}$ of dry soil sample was added to $15 \mathrm{ml}$ of $\mathrm{HCl}-\mathrm{HNO}_{3}$-HF strong acid mixture (3:1:1) to preform microwaveclose digestion. The total $\mathrm{Pb}$ content in the sample was measured using graphite furnace atomic absorption spectrophotometry (Zhu et al., 1989; Chen, 2008), the soil sample was added to $25 \mathrm{ml}$ of acetic acid at a concentration of $0.1 \mathrm{~mol} \mathrm{~L}^{-1}$, thoroughly mixed, and shaken for $3 \mathrm{~h}$, and then centrifuged at $10,000 \mathrm{r} \mathrm{min}^{-1}$ for $1.5 \mathrm{~h}$, and the process was repeated three times. Finally, the supernatant was collected for evaporation and digestion, and $\mathrm{Pb}$ content in the clear liquid sample was determined by graphite furnace atomic absorption spectrophotometry.

Statistical analysis: The data obtained were statistically analyzed using Excel 2013 and SPSS 13.0 software, and presented as mean \pm standard deviation.

\section{Results and Discussion}

Table 1 shows the total $\mathrm{Pb}$ content and available $\mathrm{Pb}$ content in the soil culture substrate. As the farmland soil samples used in this study contained a certain amount of $\mathrm{Pb}$, the actual total $\mathrm{Pb}$ content measured at each corresponding treatment level was slightly higher than the artificially added level. The data in the table indicates that the available $\mathrm{Pb}$ content accounted for approximately $15 \%$ of the total $\mathrm{Pb}$ content in the blank control sample; the available $\mathrm{Pb}$ content accounted for $17-24 \%$ of the total $\mathrm{Pb}$ content at $35-140 \mathrm{mg} \mathrm{kg}^{-1}$ treatment level. In general, the ratio of available $\mathrm{Pb}$ decreased with the increase in $\mathrm{Pb}$ treatment level. However, when the treatment concentration was $280 \mathrm{mg} \mathrm{kg}^{-1}$, the ratio increased to $28 \%$, which was inconsistent with the above mentioned trend.

This may be due to the addition of excess $\mathrm{Pb}$, short soil aging time, and limited ability of soil colloidal particles to adsorb and hold $\mathrm{Pb}$ ions. The concentration of $\mathrm{Pb}$ increased with the increase in $\mathrm{Pb}$ treatment levels. The enrichment concentration ranged from 2.54 to $89.57 \mathrm{mg} \mathrm{kg}^{-1}$; however, it was still lower than in other plants (María and María, 2014) and had a low enrichment coefficient which was between $31.16 \%$ and $45.85 \%$ and decreased with increase in $\mathrm{Pb}$ concentration. Correlation analysis of soil total $\mathrm{Pb}$ content, available $\mathrm{Pb}$ content, and plant $\mathrm{Pb}$ content (Fig. 1) showed that the plant $\mathrm{Pb}$ content was positively correlated with the total $\mathrm{Pb}$ content and available $\mathrm{Pb}$ content, and its correlation with the available $\mathrm{Pb}$ content was higher than that with the soil total $\mathrm{Pb}$ content. $\mathrm{A}$. undulatum showed an obvious growth response to different levels of $\mathrm{Pb}$ stress. In the control plants (raw soil culture without $\mathrm{Pb}$ ) or those treated with $35 \mathrm{mg} \mathrm{kg}^{-1} \mathrm{~Pb}$, the growth was normal with fresh green appearance and no obvious symptoms of toxicity.

In plants treated with $70.0-140.0 \mathrm{mg} \mathrm{kg}^{-1} \mathrm{~Pb}$, on third day, the broad-lanced leaves began to yellow and showed shrinkage and curling. Plants of family Polytrichaceae, such as A. undulatum, are sensitive to environmental humidity and the leaves shrink or curl when dry and stretch when wet. However, in this case, the freshness of leaves was not restored even after watering and the yellowing of leaves close to ground became more obvious. With increase in $\mathrm{Pb}$ concentration and duration, the degree of damage to leaves gradually increased. Under Pb stress of $280.0 \mathrm{mg} \mathrm{kg}^{-1}$, the degree of damage to leaves of the plant increased further, the sporophyte drooped, and the whole plant appeared dead. Furthermore, the originally sturdy stalk became soft and curved; the sputum gradually browned, wilted, and drooped with time; and the plants began to die. Thus, it can be concluded that $A$. undulatum is sensitive to low levels of $\mathrm{Pb}$ contaminated soil. because the

Table 1: Concentrations of total $\mathrm{Pb}$ and available $\mathrm{Pb}$ in soil and $\mathrm{Pb}$ concentration in plants at different treatment

\begin{tabular}{llll}
\hline $\begin{array}{l}\text { Pb processed concentration } \\
\left(\mathbf{m g ~ k g}^{-1}\right)\end{array}$ & $\begin{array}{l}\text { Total Pb } \\
\left(\mathrm{mg} \mathrm{kg}^{-1}\right)\end{array}$ & $\begin{array}{l}\text { Available } \mathrm{Pb} \\
\left(\mathrm{mg} \mathrm{kg}^{-1}\right)\end{array}$ & $\begin{array}{l}\text { Plant Pb enrichment } \\
\left(\mathrm{mg} \mathrm{kg}^{-1}\right)\end{array}$ \\
\hline $\mathrm{CK}$ & $6.24 \pm 1.82$ & $0.94 \pm 0.18$ & $2.54 \pm 1.16$ \\
35.0 & $40.68 \pm 3.87$ & $9.76 \pm 2.15$ & $18.65 \pm 3.67$ \\
70.0 & $74.83 \pm 5.43$ & $15.71 \pm 3.34$ & $31.89 \pm 7.76$ \\
140.0 & $148.49 \pm 11.65$ & $25.24 \pm 4.86$ & $46.27 \pm 9.48$ \\
280.0 & $286.35 \pm 22.76$ & $80.18 \pm 12.73$ & $89.57 \pm 9.89$ \\
\hline
\end{tabular}

Table 2: Physiological parameters of $A$. undulatum under different soil $\mathrm{Pb}$ stress treatments

\begin{tabular}{llll}
\hline $\begin{array}{l}\text { Pb concentration } \\
\left(\mathbf{m g ~ k g}^{-1}\right)\end{array}$ & $\begin{array}{l}\text { Chlorophyll content } \\
\left(\boldsymbol{\mu g ~ g ^ { - 1 }} \mathbf{~ F W}\right)\end{array}$ & $\begin{array}{l}\text { Soluble protein } \\
\text { content }\left(\boldsymbol{\mu g ~ g ^ { - 1 }} \mathbf{F W}\right)\end{array}$ & $\begin{array}{l}\text { MDA content } \\
\left(\mathbf{n m o l ~ m g p r o t}^{-1}\right)\end{array}$ \\
\hline $\mathrm{CK}$ & $22.45 \pm 3.36$ & $351.13 \pm 24.77$ & $3.17 \pm 0.51$ \\
35.0 & $21.17 \pm 3.17$ & $345.76 \pm 24.64$ & $3.32 \pm 0.68$ \\
70.0 & $18.12 \pm 2.95$ & $306.54 \pm 22.58$ & $4.79 \pm 0.82$ \\
140.0 & $13.76 \pm 2.13$ & $271.77 \pm 21.65$ & $6.84 \pm 1.34$ \\
280.0 & $9.27 \pm 1.87$ & $231.68 \pm 19.16$ & $9.87 \pm 1.85$ \\
\hline
\end{tabular}



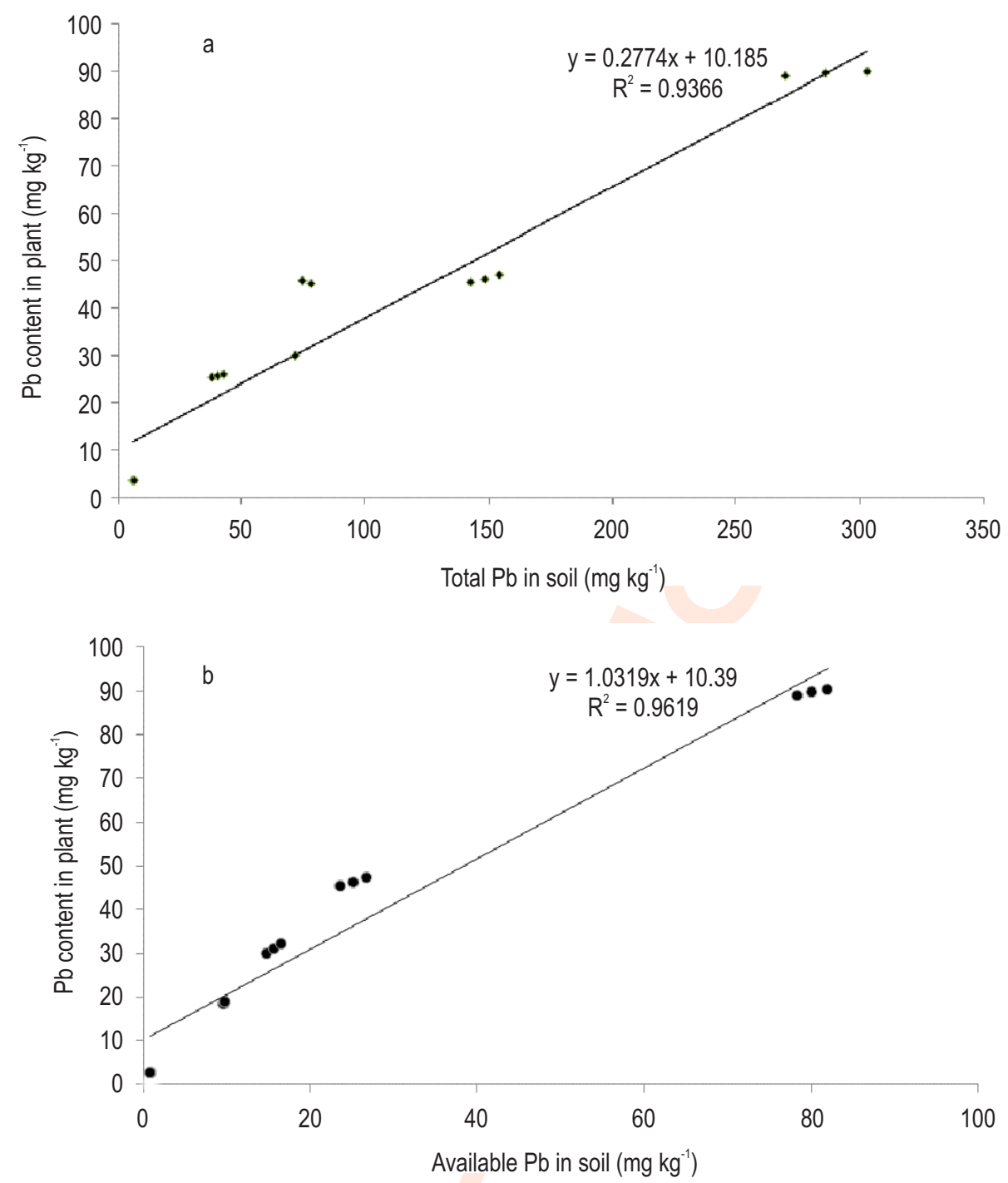

Fig. 1: Correlation between plant $\mathrm{Pb}$ concentrations and soil total (a) $\mathrm{Pb}$ available and (b) $\mathrm{Pb}$ concentrations.

minimum $\mathrm{Pb}$ concentration in this experiment was only the $\mathrm{Pb}$ background value for primary soil. Therefore, $A$. undulatum is an ideal plant to monitor Pb contamination in soil. Recently, many bryophytes such as peat moss, entodon moss, hypnum moss, and mat moss have been used to monitor atmospheric heavy metal pollution in different regions. Cypress-leaved plait-moss and square pleurochaete moss, widely distributed in the Mediterranean region, were not only effective in monitoring the pollution levels of $\mathrm{Pb}, \mathrm{Cd}$, and $\mathrm{Hg}$ in the local atmosphere, but also in identifying and locating the source of nitrogen emissions based on isotope labeling of nitrogen in plants (Izquieta-Rojano et al., 2016). Mossy bags containing peat moss have become a standardized atmosphere-monitoring method in countries like Finland (Lodenius, 2013; Boquete et al., 2014). Li et al. (2014) conducted heavy metal content analyses using several bryophytes in the Laoshan Area of Qingdao for two consecutive years and obtained satisfactory air pollution monitoring results. However, different kinds of moss are needed to identify different pollutants. In practical application, the morphology of bryophytes is often used to visually reflect environmental pollution.

Therefore, selecting plants of large size and high sensitivity to a specific pollutant can be useful for on-site sampling and pollution indicator. The bryophyte used in this study was sensitive to $\mathrm{Pb}$ contamination in soil, and it was also of a suitable size as mature plant height of sporophyte can reach $6-8 \mathrm{~cm}$ with a simple body structure, sporophyte parasitic on gametophytes, and uniform structure of monolayers of stems, leaves, and other organs, all of which are suitable for observation of growth indicators and microstructure. The physiological parameters of plants were significantly affected by $\mathrm{Pb}$ contamination in soil (Table 2). When the concentration of $\mathrm{Pb}$ reached $70 \mathrm{mg} \mathrm{kg}^{-1}$, the chlorophyll and soluble protein content of plants reduced by $19.28 \%$ and $12.7 \%$, respectively, as compared to control plants, with $51.1 \%$ increase in the MDA content. 

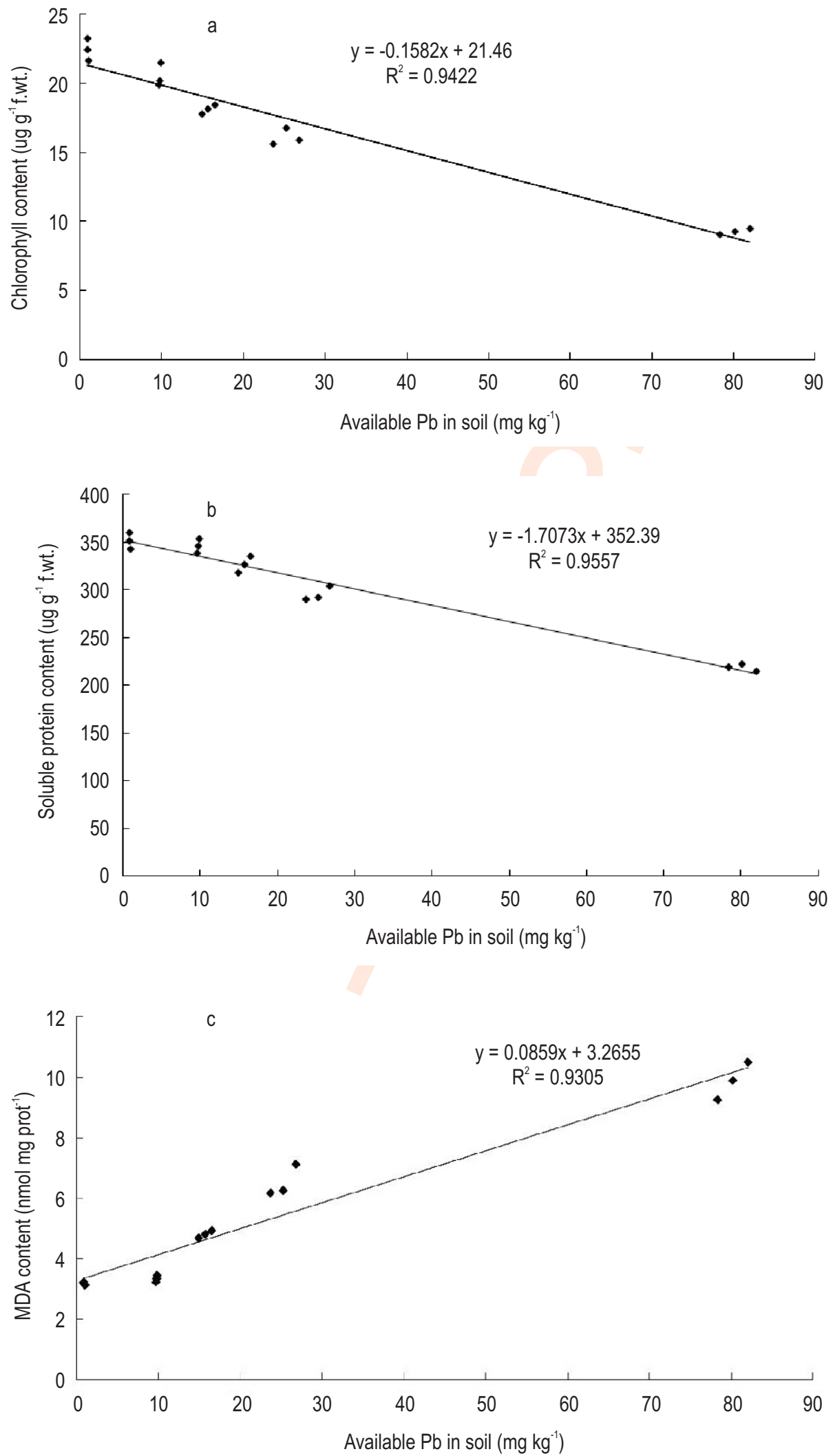

Fig. 2: Correlation between the physiological parameters (a: Chlorophyll; b: Solube protein and c: MDA content) of $A$. undulatum and soil available Pb concentrations. 
The physiological parameters of $A$. undulatum changed even more significantly at $140.0 \mathrm{mg} \mathrm{kg}{ }^{-1}$ soil treatment, with chlorophyll and soluble protein content decreasing from $38.8 \%$ to $58.8 \%$ and $22.6 \%$ to $34.1 \%$, respectively, as compared to control plants. The increase in MDA content, was 1.16-2.11 times higher than control. As chlorophyll and soluble protein are closely associated with plant growth, stresses that reduce their content in $A$. undulatum could affect plant growth. Malondialdehyde is a substance produced due to peroxidation of membrane lipids when plant cell membrane is attacked by heavy metal ions. An increase in MDA content usually indicates enhanced membrane lipid peroxidation, i.e., the plant exhibits a stress response to adverse conditions (Wang et al., 2009; Li et al., 2012; Li et al., 2013). These three physiological parameters are used as indicator of heavy metal pollution in bryophytes. In Taxiphyllum taxirameum and Eurhynchium eustegium, soluble protein content, membrane lipid peroxidation, and enzyme activity were affected due to $\mathrm{Cd}$ and $\mathrm{Pb}$ contamination (Chen et al., 2015). The anthocyanin content and chlorophyll fluorescence values also showed significant changes under stress, which could be used to distinguish the pollution level and toxic effects of heavy metals such as $\mathrm{Pb}$ and $\mathrm{Cd}$. In some plants like Tillandsia usneoides, chlorophyll content, MDA concentration, and antioxidant enzyme activity can be used to monitor formaldehyde pollution in air through physiological and biochemical parameters (Li et al., 2013).

The growth characteristics of $A$. undulatum under $\mathrm{Pb}$ pollution indicated that the bryophyte show strong sensitivity to $\mathrm{Pb}$ pollution in soil, and its tolerance to $\mathrm{Pb}$ was significantly lower than other plant species (Gjengedal and Steinnes, 1994; Liu et al., 2008; Geffard et al., 2010; Udovic et al., 2013; Salazar and Pignata, 2014). This suggest that bryophyte are suitable for monitoring $\mathrm{Pb}$ contamination soil. It should also be noted that this experiment was carried out under a small gradient of Pb stress levels, i.e., four treatment concentration levels were established and the difference between the concentrations were too large to reflect the actual $\mathrm{Pb}$ pollution response curve. Therefore, specific "dose-effect relationship" between the two needs to be studied further. To identify the relationship between plant growth status and soil bioavailability, correlation between the changes in physiological parameters of $A$. undulatum and soil available Pb content was analyzed (Fig. 2a-c). The results showed a significant negative correlation between the available $\mathrm{Pb}$ content in soil and chlorophyll content and soluble protein content in $A$. undulatum $\left(R^{2}=0.9422\right.$ and 0.9557 , respectively). A significant positive correlation was observed between available $\mathrm{Pb}$ content and MDA content $\left(R^{2}=0.9305\right)$. The results demonstrate that the available $\mathrm{Pb}$ content in soil was closely related to growth of $A$. undulatum and affected its physiological state. Heavy metals such as $\mathrm{Pb}$ persist in soil for a longer time. Due to the influence of internal and external environmental factors, such as oil temperature and humidity, soil acidification process caused by rainfall, soil colloidal particle weathering, mutual antagonism of various metal ions in soil, complexation between chelating agents and lead ions that enter the outside world, causes mutual transformation between different chemical forms (Bolan et al., 2014).

Various dynamic physical and chemical processes such as adsorption-desorption, dissolution-precipitation, and oxidationreduction; the bioavailability and toxicity also change constantly
(Bolan et al., 2014). Previous studies (Remon et al., 2013; Tariq \& Ashraf, 2013; Wang et al., 2014) indicate that the absolute value of heavy metals in soil can be used as a basis for measuring the degree of pollution, but its bioavailability is a more scientific parameter for evaluation because heavy metals in soil affect the growth of plants depend only on the proportion in the available state that can be absorbed and utilized by the plants. To a certain extent, the plant monitoring method can evaluate bioavailability of heavy metals. In a study, Pinus sylvestris was used to alleviate soil heavy metal pollution, the heavy metal content in pine needles indicated the bioavailability of heavy metals in soil, and also reflected the physico-chemical properties of soil indirectly (Pietrzykowski et al., 2014). After treatment of heavy metal waste liquid with corn seedlings, the biotoxicity and repairing effect of heavy metals in wastewater were evaluated according to the change in the chlorophyll fluorescence value in leaves and the inhibition degree of photosynthetic effect in cyanobacteria (Lucas et al., 2013). Owing to these advantages and application value of bryophytes, $A$. undulatum was selected as a test plants to indicate and evaluate the degree of $\mathrm{Pb}$ pollution in soil and its bioavailability.

Therefore, compared with total $\mathrm{Pb}$ in soil, available $\mathrm{Pb}$ is more suitable for reflecting $\mathrm{Pb}$ contamination in soil and ecological safety. $A$. undulatum was susceptible to $\mathrm{Pb}$ toxicity in soil, and showed a noticeable growth and physiological response, which revealed its high sensitivity and low tolerance to $\mathrm{Pb}$ pollution. Physiological parameters such as chlorophyll, soluble protein, and MDA can be used as indicators to evaluate soil $\mathrm{Pb}$ pollution levels and bioavailability. Therefore, the study confirmed that $A$. undulatum has a high application value in monitoring soil $\mathrm{Pb}$ pollution.

\section{Acknowledgments}

This study was funded by the Chinese National Natural Science Foundation (31700332), Hunan Natural Science Foundation (2016JJ4015; 2019JJ40013), Hunan Science \& Technology Innovation Platform and Talent Plan (2017TP2006, 2018TP1042) and Yiyang Science and Technology Innovation Project (2018YR01).

\section{Add-on Information}

Author' contribution: N. Yang: Participate the whole process and write the manuscript, $\mathbf{M}$. Dong: Guide the experiment and manuscript, Z. Xu: Guide the manuscript, X. Zhou: Field work and experiment, Z. Xu: Field work and W. Ku: Experiment.

Research content: The research contents is original and has not been published elsewhere

\section{Ethical approval: NotApplicable}

Conflict of interest: The author declares that there is no conflict of interest.

\section{Data from other sources: NotApplicable}

Consent to publish: Author agree to publish the paper in Journal of Environmental Biology. 


\section{References}

Aboal J.R., M.T. Boquete, A. Carballeira, A. Casanova and S Debén: Quantification of the overall measurement uncertainty associated with the passive moss biomonitoring technique: Sample collection and processing. Environ. Pollut., 224, 235-242 (2017).

Abril, G.A., E.D. Wannaz and A.C. Mateos: Biomonitoring of airborne particulate matter emitted from a cement plant and comparison with dispersion modelling results. Atmos. Environ., 82, 154-163 (2014).

Basile, A., S. Sorbo and M. Cardi: Effects of heavy metals on ultrastructure and Hsp70 induction in Lemna minor L. exposed to water along the Sarno River, Italy. Ecotox. Environ. Safe., 114, 93-101 (2015).

Bolan, N., A. Kunhikrishnan and R. Thangarajan: Remediation of heavy metal (loid) s contaminated soils-To mobilize or to immobilize. J. Hazard. Mater., 266, 141-166 (2014).

Boquete, M.T., J.R. Aboal and A. Carballeira: Effect of age on the heavy metal concentration in segments of Pseudoscleropodium purum and the biomonitoring of atmospheric deposition of metals. Atmos. Environ., 86, 28-34 (2014).

Chen, Y.E., J.M. Cui and J.C. Yang: Biomonitoring heavy metal contaminations by moss visible parameters. J. Hazard. Mater., 296, 201-209 (2015).

Chen, Y.X.: Heavy metals pollution chemistry in soil-plant system. Beiijing, Science Press (2008) (In Chinese).

Conti, M.E., and G. Cecchetti: Biological monitoring: lichens as bioindicators of air pollution assessment-a review. Environ. Pollut., 114, 471-492 (2001).

Debén S., J.A. Fernández, A. Carballeira, G. Kosior and J.R. Aboal: Improving active biomonitoring in aquatic environments: The optimal number and position of moss bags. Ecol. Indic., 93, 753$758(2018)$

Esposito, S., S. Loppi, F. Monaci, L. Paoli and A. Vannini: In-field and invitro study of the moss Leptodictyum riparium as bioindicator of toxic metal pollution in the aquatic environment: Ultrastructural damage, oxidative stress and HSP70 induction. PLOS ONE, 13, e0195717 (2018)

Geffard, A., H. Sartelet and J. Garric: Subcellular compartmentalization of cadmium, nickel and lead in Gammarus fossarum: Comparison of methods. Chemosphere, 78, 822-829 (2010).

Gjengedal, E. and E. Steinnes: The mobility of metals in the soil-plant system in manipulated catchments: Plant species suitable for biomonitoring of Cd, Pb, Zn and Rb. Ecol. Eng., 3, 267-278 (1994).

Harmens, H. and D. Norris: The Participants of the Moss Survey: Spatial and temporal trends in heavy metal accumulation in mosses in Europe (1990-2005). Programme Coordination Centre for the ICP Vegetation, Centre for Ecology and Hydrology, Environment Centre Wales, Bangor, UK, 54 p. (2008).

Harguinteguy, C. A., M. L. Pignata and A. Fernandez-Cirelli: Nickel, lead and zinc accumulation and performance in relation to their use in phytoremediation of macrophytes Myriophyllum aquaticum and Egeria densa. Ecol. Eng., 82, 512-516 (2015).

Izquieta-Rojano, S., D. Elustondo and A. Ederra: Pleurochaete squarrosa (Brid.) Lindb. as an alternative moss species for biomonitoring surveys of heavy metal, nitrogen deposition and $\delta^{15} \mathrm{~N}$ signatures in a Mediterranean area. Ecol. Indic., 60, 1221-1228 (2016).

Li, F.T., J.M. Qi and G.Y. Zhang: Effect of Cadmium stress on the growth, antioxidative enzymes and lipid peroxidation in two kenaf (Hibiscus cannabinus L.) plant seedlings. J. Integr. Agr., 12, 610$620(2013)$.

Li, J.L., P. Li, H.R. Wang and G.L. Zheng: Optimization study of heavy metal pollution in-situ monitoring points in waste tailings reservoir based on correspondence analysis method. Chin. J. Environ.
Eng., 7, 1451-1458 (2013) (In Chinese)

Li, Q., X. Ji, E. H. Wang, H. M. Gao, and Y. J. Yi: Using bryophytes as biomonitor atmospheric heavy metal deposition in the city of Qingdao. Chin. Bull. Bot., 49, 569-577 (2014) (In Chinese).

Li, X., M. X. Zhao, and L. P. Guo: Effect of cadmium on photosynthetic pigments, lipid peroxidation, antioxidants, and artemisinin in hydroponically grown Artemisia annua. J. Envir. Sci., 24, 1511$1518(2012)$

Liu, J.N., Q. X. Zhou and T. Sun: Growth responses of three ornamental plants to $\mathrm{Cd}$ and $\mathrm{Cd}-\mathrm{Pb}$ stress and their metal accumulation characteristics. J. Hazard. Mater., 151, 261-267 (2008).

Lodenius M.: Use of plants for biomonitoring of airborne mercury in contaminated areas. Environ. Res., 125, 113-123 (2013).

Lucas, G.J.A., L. Grijalbo and B. Ramos: Combined phytoremediation of metal-working fluids with maize plants inoculated with different microorganisms and toxicity assessment of the phytoremediated waste. Chemosphere, 90, 2654-2661 (2013).

María, J.S. and L.P. María: Lead accumulation in plants grown in polluted soils. Screening of native species for phytoremediation. $J$. Geochem. Explor., 137, 29-36 (2014).

Pietrzykowski, M., J. Socha and D.N.S. Van: Linking heavy metal bioavailability $(\mathrm{Cd}, \mathrm{Cu}, \mathrm{Zn}$ and $\mathrm{Pb})$ in Scots pine needles to soil properties in reclaimed mine areas. Sci. Total. Environ., 470-471, 501-510 (2014).

Remon, E., J.L. Bouchardon and G.M. Le: Are plants useful as accumulation indicators of metal bioavailability. Environ. Pollut., 175, 1-7 (2013).

Salazar, M.J. and M.L. Pignata: Lead accumulation in plants grown in polluted soils. Screening of native species for phytoremediation. J. Geochem. Explor., 137, 29-36 (2014).

Shibata, M., T. Konno and R. Akaike: Phytoremediation of $\mathrm{Pb}$ contaminated soil with polymer-coated EDTA. Plant. Soil., 290, 201-208 (2007).

Sun J., B.Q. Tie, Z. Qian, S. W. Yang, X. Q. Mao, T. Zhao, R. Luo and A. Isao: Eco-toxicological effect of compound stress of $\mathrm{Cu}, \mathrm{Cd}, \mathrm{Pb}, \mathrm{Zn}$ and As on Juncus effuses. Soils, 39, 279 285 (2007) (In Chinese).

Tang, Y.T., R.L. Qiu, X.W. Zeng, R.R. Ying, F.M. Yu and X.Y. Zhou: Lead, zinc, cadmium hyperaccumulation and growth stimulation in Arabis paniculata Franch. Environ. Exp. Bot., 66, 126-134 (2009).

Tariq, S.R. and A. Ashraf: Comparative evaluation of phytoremediation of metal contaminated soil of firing range by four different plant species. Arab. J. Chem., 18, 806-814 (2013).

Udovic, M., D. Drobne and D. Lestan: An in vivo invertebrate bioassay of $\mathrm{Pb}, \mathrm{Zn}$ and $\mathrm{Cd}$ stabilization incontaminated soil. Chemosphere, 92, 1105-1110 (2013).

Wang, C., S. H. Zhang and P. F. Wang: The effect of excess Zn on mineral nutrition and antioxidative response in rapeseed seedlings. Chemosphere, 75, 1468-1476 (2009).

Wang, Q. Y., D. M. Zhou and L. Cang: Bioavailability of soil copper from different sources: Integrating chemical approaches with biological indicators. Pedosphere, 24, 145-152 (2014).

Yang, M.W.: Study on rapid determination of chlorophyll content of leaves. Chin. J. Spectro. Lab., 19, 478-481 (2002) (In Chinese).

Zhou, Q., J. Zhang, J. Fu, J. Shi and G. Jiang: Biomonitoring: An appealing tool for assessment of metal pollution in the aquatic ecosystem. Anal. Chim. Acta., 606, 135-150 (2008).

Zhou, Q. X., Y. Teng, S. H. Zhan and L. Tong: Fundamental problems to be solved in research on soil-environmental criteria/standards. $J$. Agro-Environ. Sci., 33, 1-14 (2014) (In Chinese).

Zhu, Y. W., R. S. Shen, and Q. W. Qian: Sequential extraction for five components of heavy metals in soil. Soils, 4, 163-166 (1989) (In Chinese). 